
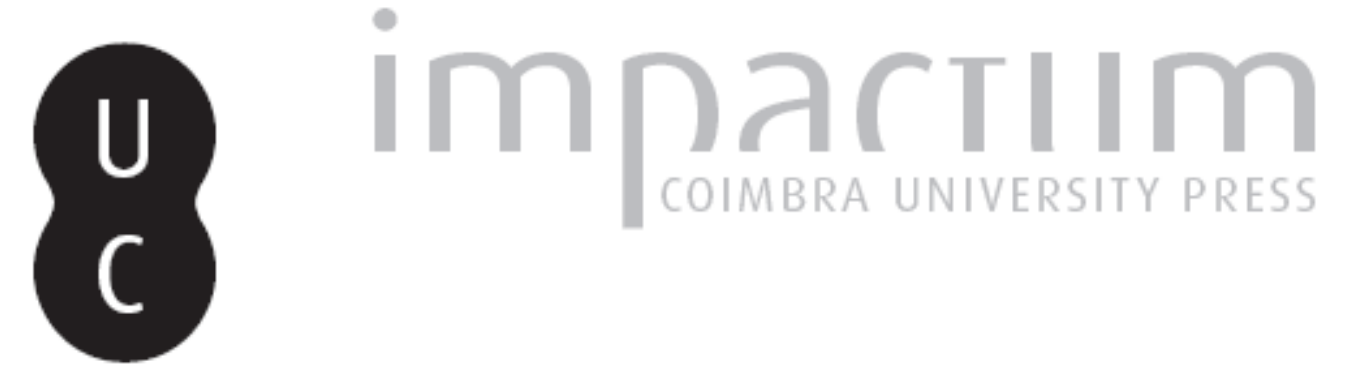

\title{
Secularização e tolerância
}

\section{Autor(es): $\quad$ Borges, Anselmo}

Publicado por: Imprensa da Universidade de Coimbra

URL persistente:

URI:http://hdl.handle.net/10316.2/43694

DOI:

DOI:https://doi.org/10.14195/2183-8925_25_3

Accessed : $\quad$ 26-Apr-2023 13:00:03

A navegação consulta e descarregamento dos títulos inseridos nas Bibliotecas Digitais UC Digitalis, UC Pombalina e UC Impactum, pressupõem a aceitação plena e sem reservas dos Termos e Condições de Uso destas Bibliotecas Digitais, disponíveis em https://digitalis.uc.pt/pt-pt/termos.

Conforme exposto nos referidos Termos e Condições de Uso, o descarregamento de títulos de acesso restrito requer uma licença válida de autorização devendo o utilizador aceder ao(s) documento(s) a partir de um endereço de IP da instituição detentora da supramencionada licença.

Ao utilizador é apenas permitido o descarregamento para uso pessoal, pelo que o emprego do(s) título(s) descarregado(s) para outro fim, designadamente comercial, carece de autorização do respetivo autor ou editor da obra.

Na medida em que todas as obras da UC Digitalis se encontram protegidas pelo Código do Direito de Autor e Direitos Conexos e demais legislação aplicável, toda a cópia, parcial ou total, deste documento, nos casos em que é legalmente admitida, deverá conter ou fazer-se acompanhar por este aviso.

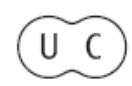



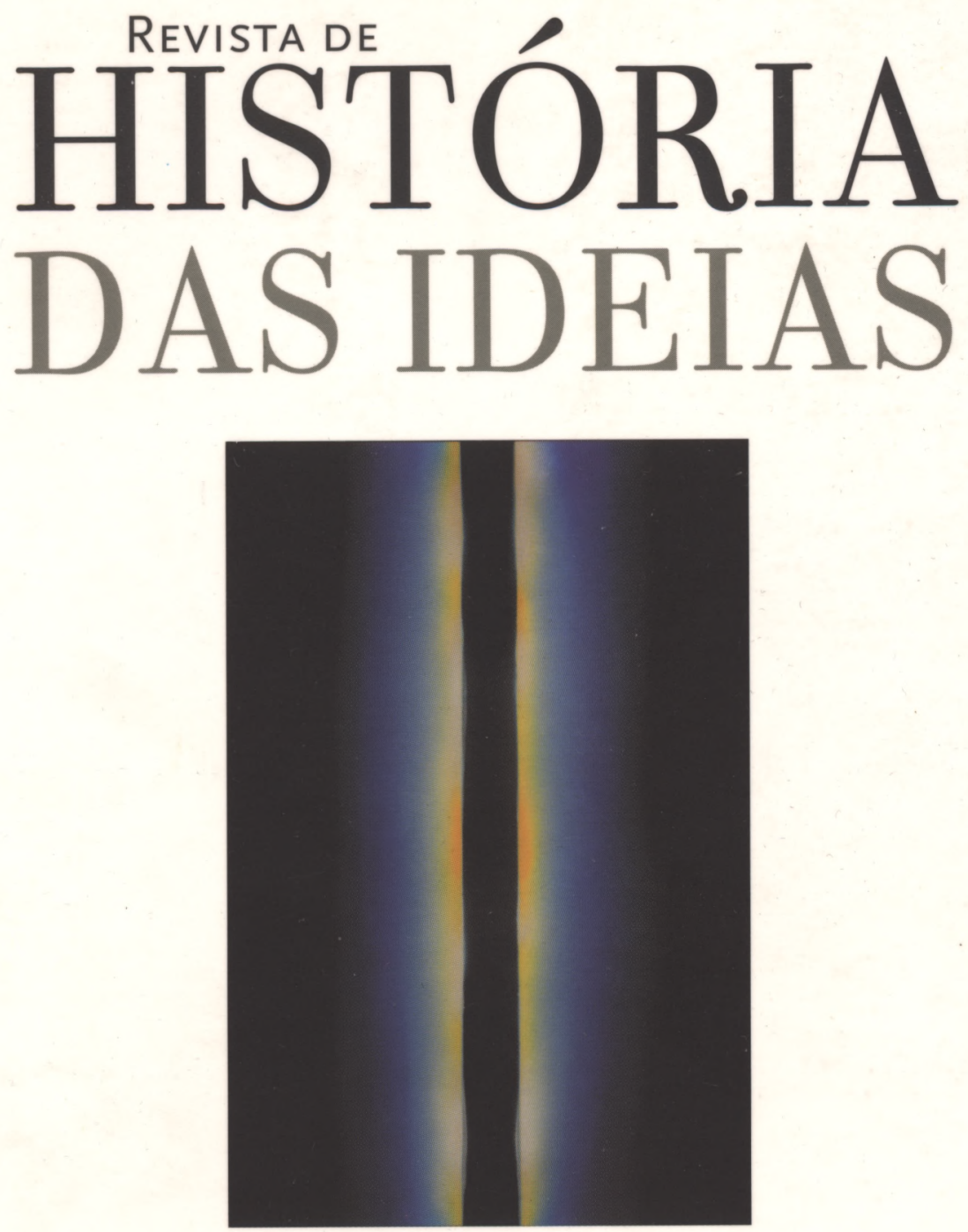

TOLERÂNCIAS, INTOLERÂNCIAS

\author{
Volume 25, 2004
}

INSTITUTO DE HISTÓRIA E TEORIA DAS IDEIAS

Faculdade de Letras da Universidade de CoImbra 


\section{SECULARIZAÇÃO E TOLERÂNCIA}

As periódicas profecias a anunciar o fim da religião não se confirmaram. Pelo contrário, assiste-se ao retorno do religioso, sob as formas mais diversas, incluindo a do "religioso selvagem". A religiosidade é uma dimensão profunda e constitutiva do ser humano, como a música, a ética, a estética, o direito... A influência decisiva do factor religioso na cultura, na vida colectiva, na economia, nas atitudes e comportamentos não pode ser ignorada. Na presente situação, chama particularmente a atenção a importância da religião/religiões na política e nos conflitos em curso.

Há anos que Hans Küng não se cansa de repetir e sublinhar que o diálogo e a paz entre as religiões são condição essencial para a paz entre as nações: "Não haverá paz entre as nações sem paz entre as religiões. Não haverá paz entre as religiões sem diálogo entre as religiões. Não haverá diálogo entre as religiões sem critérios éticos globais. Não haverá sobrevivência do nosso globo sem um ethos global, um ethos mundial"(1).

Pela sua própria natureza, esse diálogo implica um consenso ético mínimo, tal como ficou estabelecido na Declaração Princípios de uma ética mundial, assinada em Setembro de 1993, em Chicago, pelo Parlamento das Religiões do Mundo. $O$ texto fora essencialmente preparado por Hans Küng. Trata-se de um consenso de base, mínimo, referente a valores

* Faculdade de Letras da Universidade de Coimbra.

(1) Hans Küng, Spurensuche. Die Weltreligionen aufdem Weg, Munique, Zurique, $1999^{2}$, p. 306. 
vinculantes, a critérios e normas inamovíveis e a atitudes morais fundamentais. Supõe-se que estes mínimos éticos, que assentam na constatação de uma convergência já existente nas tradições religiosas, podem ser assumidos por todos os seres humanos, independentemente da sua relação com a religião ${ }^{(2)}$.

Neste consenso mínimo de base, a exigência fundamental é: todo o ser humano deve ser tratado humanamente. Porquê? Todo o ser humano, sem distinção de sexo, idade, raça, classe, cor, língua, religião, ideias políticas, condição social, possui uma dignidade inviolável e inalienável. Por outro lado, para agir de forma verdadeiramente humana, vale, antes de mais, a regra de ouro: "Não faças aos outros o que não queres que te façam a ti" (formulada positivamente: "Faz aos outros o que queres que te façam a ti"). Nesta regra, encontra-se a norma incondicionada, absoluta, que deve orientar todas as esferas da vida, e que vale para a familia e para as comunidades, para raças, nações e religiões. Esta regra de ouro concretiza-se em quatro directrizes ou orientações antiquíssimas e inalteráveis: comprometimento com uma cultura da não-violência e do respeito pela vida (não matarás: respeita toda a vida); comprometimento com uma cultura da solidariedade e com uma ordem económica justa (não roubarás: age com justiça); comprometimento com uma cultura da tolerância e uma vida vivida com veracidade (não mentirás: fala e age com verdade); comprometimento com uma cultura da igualdade de direitos e com uma irmandade entre homem e mulher (não prostituirás nem te prostituirás: respeitai-vos e amai-vos mutuamente). No espírito de uma declaração de ética mundial, não se deu entrada a questões morais discutidas em todas as religiões e nações, como o aborto, a homossexualidade ou a eutanásia.

Neste contexto, é, porém, fundamental sublinhar que, para este diálogo em ordem à paz, há dois pressupostos essenciais. O primeiro refere-se à secularização, portanto, à autonomia das realidades terrestres ou seculares, com a consequente separação da religião e da política (I). O outro tem como centro a problemática da revelação divina e da verdade (II). A presente exposição tem como objecto reflectir brevemente sobre estes dois núcleos de questões.

(2) "Parlamento de las religiones del mundo: Principios de una ética mundial", Isegoría, vol. 10, 1994, pp. 7-21. 
Seguiu-se até há pouco a opinião de $\mathrm{H}$. Lübbe, segundo a qual a palavra "secularizar" (séculariser) teria sido utilizada pela primeira vez em Munique a 8 de Maio de 1646 pelo legado francês Logueville durante as negociações para pôr termo à Guerra dos Trinta Anos (1618-1648). A palavra "secularização" designava a transferência para o eleitor de Brandeburgo de territórios pertencentes a vários mosteiros, tendo sido com este sentido que figura no Tratado de Vestefália (1648): "secularização dos bens eclesiásticos" - apropriação pelo "mundo" de bens pertencentes à Igreja. No entanto, segundo investigações de H. W. Strätz, já no século anterior alguns canonistas franceses, concretamente Jean Papon e Pierre Grégoire, o tinham usado para referir o abandono do sacerdócio ou da vida religiosa. Também aqui, portanto, o significado é o mesmo: passar da "Igreja" para o "mundo". O primeiro sentido do termo foi, pois, jurídico. No século XIX, começou a assumir um significado cultural, designando "um processo de mundanização vivido pela sociedade no seu conjunto"(3).

Em ordem à compreensão deste sentido, ajuda uma passagem pela etimologia da palavra. Secularização provém do latim "saeculum", que, no latim clássico, significava "século" (período de cem anos) e também "idade" e "época". No latim eclesiástico, adquiriu o significado de "o mundo", "a vida do mundo" e "o espírito do mundo", sendo por esta via que se chegou ao sentido da palavra "secularização". Por sua vez, "saeculum" com o significado de "mundo" contraposto a "Igreja", no latim eclesiástico, deve-se à famosa tradução da Bíblia para o latim por São Jerónimo, conhecida por "Vulgata". De facto, no original grego do Novo Testamento, a palavra kósmos significa mundo, tanto no sentido positivo como no sentido negativo. Há exemplos clássicos para o primeiro e para o segundo caso, respectivamente: "Deus amou tanto o mundo que lhe entregou o seu Filho único"(4), "os filhos deste mundo são mais sagazes do que os filhos da luz" ou "quem quiser ser amigo deste mundo torna-se inimigo de Deus"(5). Ora, se no primeiro sentido, São Jerónimo

(3) Luis González-Carvajal, Cristianismo y secularización, Santander, 2003, pp. 10-11.

(4) Jn $3,16$.

(5) Lc 16, 8 e $\operatorname{Tg} 4,4$. 
não hesitou em traduzir kósmos por mundus, no segundo, essa tradução seria quase incompreensível, pois até etimologicamente mundus significa ordem e beleza (atente-se em imundo). Por isso, decidiu-se pela palavra saeculum, com a acepção de mundo pecaminoso e fechado a Deus, portanto, "o próprio tempo enquanto contraposto à eternidade ("este século" contraposto ao "século futuro"), sendo assim que saeculum começou a significar "mundo" oposto a "Igreja"(6).

Ainda hoje continuam os debates acalorados, sobretudo no domínio teológico, sobre a secularização: se não falta quem a condena, pois estaria na base do afastamento da religião, outros saúdam-na como condição da purificação religiosa e da paz. Há múltiplos sentidos de secularização. Situando-se sobretudo no domínio das ciências sociais, Larry Shiner analisou seis significados diferentes ${ }^{(7)}$. Ela pode ser vista como "eclipse do sagrado", como "autonomia do profano", como "privatização da religião", como "retrocesso das crenças e práticas religiosas", como "mundanização das próprias Igrejas"(8). Aqui, interessa-nos sobretudo o segundo sentido: a secularização enquanto autonomia do profano.

Nas suas origens, o cristianismo apareceu como uma religião surpreendentemente "secular". Nas comunidades cristãs, evidentemente, havia ministérios e carismas, mas não existia uma casta sacerdotal. A liturgia consistia essencialmente numa refeição fraterna nas casas dos cristãos. Os presbíteros e quem presidia vestiam normalmente, mesmo na celebração eucarística. Usava-se a língua habitual (primeiro, a koiné e, depois, o latim), não havia templos dedicados ao culto nem língua sagrada. Foi tal o choque sobretudo por causa da inexistência de sacrifícios que os cristãos foram acusados de ateísmo.

Com o reconhecimento do cristianismo como religião oficial do Império romano tudo se foi modificando. Apareceram os templos e a mesa comum da refeição familiar deu lugar ao altar. Se, no Novo Testamento, todos os cristãos eram considerados "santos", impôs-se a distinção entre o clero (a parte "sagrada") e os leigos (a parte "profana"). Ergueram-se barreiras entre o "presbitério" e o resto do templo: o lugar

(6) Luis González-Carvajal, ob. cit., pp. 8-9.

(7) L. Shiner, "The Concept of Secularization in Empirical Research", Journal for the Scientific Study of Religion, vol. 6, 1967, pp. 207-220.

(8) Luis González-Carvajal, ob. cit., pp. 11-12. 
próprio do sacrifício eucarístico ficava reservado exclusivamente aos sacerdotes, que foram arrancados à vida normal e ficaram sujeitos à lei do celibato. As orações litúrgicas, que antes eram espontâneas, fixaram-se em fórmulas rígidas, com uma verdadeira obsessão por um ritual quase mágico. Só o clero podia distribuir a comunhão, pois as mãos "impuras" dos fiéis não deviam tocar os santos mistérios ${ }^{(9)}$. Ora, ao contrário do que poderia pensar-se, de toda esta "sacralização" não derivou uma vida cristã mais autêntica, pois "quanto mais sagrada é uma liturgia, isto é, quanto mais separada da vida ordinária, tanto menos compromete o indivíduo"(10).

Contra o preceito de Cristo que delimitava campos de poder - "Dai a César o que é de César e a Deus o que é de Deus" (11) _, Constantino, apesar da sua "conversão" ao cristianismo, não esqueceu a divinização imperial e intrometeu-se nas questões da Igreja, convocando concilios, determinando as suas decisões, nomeando e desterrando patriarcas e bispos... Os reis visigodos e os francos reclamaram o carácter sacral da realeza. Como os sacerdotes, os monarcas eram ungidos com óleo e governavam em nome de Deus. Carlos Magno escreveu ao Papa Leão III uma carta, na qual se declarava a si mesmo "senhor e pai, rei e sacerdote, director e guia de todos os cristãos". No século XI, o imperador foi representado com a pomba do Espírito Santo, e o arcebispo de Mainz chamou "vigário de Cristo" a Conrado II ${ }^{(12)}$. O Papa Bonifácio VIII formulou em 1302 a teoria das duas espadas, segundo a qual o Papa detém o poder espiritual e temporal, mas, se exerce o primeiro directamente, delega o segundo nos príncipes, que o exercem em representação do $\mathrm{Papa}^{(13)}$. Para se defenderem do Papa, os monarcas reivindicaram o direito divino dos reis.

(9) Idem, ob. cit., pp. 129-131.

(10) Mauro Rodríguez, Desacralización: único camino, Barcelona, 1974, p. 38.

(11) Mt 22, 21.

(12) Luis González-Carvajal, ob. cit., p. 32.

(13) "Unam Sanctam", Dz 873: "In hac eiusque potestate duos esse gladios, spiritualem videlicet et temporalem, evangelicis instruimur... Uterque ergo est in potestate Ecclesiae, spiritualis scilicet gladius et materialis. Sed is quidem pro Ecclesia, illa vero $a b$ Ecclesia exercendus. Ille sacerdotis, is manu regum et militum, sed ad nutum et patientiam sacerdotis. Oportet autem gladium esse sub gladio, et temporalem auctoritatem spirituali subiici potestati." 
Mesmo Lutero afirmou o carácter divino de toda a autoridade estabelecida, com todas as consequências dramáticas conhecidas, concretamente na guerra dos camponeses. Com a sua doutrina dos dois reinos contribuiu, porém, para o processo da secularização. Segundo o Reformador, há o reino de Deus (pequenas comunidades de cristãos autênticos) e o reino do mundo (os domínios profanos). Para "governar o mundo segundo o Evangelho", seria preciso "encher o mundo de cristãos verdadeiros antes de governá-lo cristã e evangelicamente". Mas isso nunca será possível, "porque o mundo e a multidão não são nem serão cristãos, mesmo que todos estejam baptizados e se chamem assim". De facto, o mundo é mau, e "entre milhares dificilmente se encontra um verdadeiro cristão". Assim, é tarefa dos cristãos governar as realidades profanas apenas mediante a razão humana, sem interferência da fé. A "salvação" do mundo pertence a Deus, que o fará no fim dos tempos, sem colaboração dos homens ${ }^{(14)}$.

Numa história cujos marcos não é possível apresentar aqui pormenorizadamente, a Modernidade impôs a secularização e o princípio da laicidade, pondo fim a equívocos próprios da Cristandade. A razão moderna reivindicou a emancipação e a autonomia das diferentes esferas seculares: filosofia, ciência - perguntamos hoje como foi possível o caso Galileu -, política, medicina, economia, estética, a própria moral. Trata-se de um processo nem sempre pacífico, pois não faltaram os conflitos azedos com a Igreja católica e as Igrejas cristãs em geral. Por exemplo, o Papa Pio VI condenou "a detestável filosofia dos direitos humanos" ${ }^{(15)} e$ o Papa Pio IX, no Syllabus, pretendeu estabelecer o elenco dos erros modernos, entre os quais se contam a liberdade de expressão e de religião. O problema é, portanto, outro. Mesmo que se não esteja completamente de acordo com autores que como F. Gogarten sustentam que a secularização "é um fenómeno pós-cristão, isto é, um fenómeno produzido pela fé cristã"(16), é necessário afirmar que, ainda que, de facto, tenha tido de impor-se contra a Igreja oficial, a secularização tem raízes bíblicas.

(14) Martín Lutero, La autoridad secular, in Obras de Martín Lutero, t. 2, Buenos Aires, 1974, pp. 134-135. Cf. Luis González-Carvajal, ob. cit., pp. 55-56.

(15) Hans Küng, ob. cit., p. 263.

(16) Friedrich Gogarten, Destino y esperanzas del mundo moderno, Madrid, Barcelona, 1971, p. 144. 
A Bíblia é essencialmente dessacralizadora da natureza, da história e da política. Os gregos não tiveram a ideia de criação, e ao seu conceito de geração, que implica um processo necessitante, está subjacente alguma forma de panteísmo. Tales, por exemplo, afirmava que "mesmo os seres aparentemente inanimados podem estar 'vivos'; tudo está cheio de deuses"(17). Precisamente ao conceito de geração, da filosofia grega, opõe-se o da criação ex nihilo, da tradição judeo-cristã, fundamento da aliança do Deus-Liberdade com homens e mulheres livres. ODeus transcendente pessoal cria o mundo a partir do nada e por um acto de pura liberdade de amor. A criação assim entendida implica uma diferença qualitativa infinita entre Deus e a criatura e a real autonomia do mundo, que é mundano e não divino. Deus põe, portanto, a diferença dele próprio, de tal modo que o posto é distinto de Deus, e, assim, realidade autêntica e não simples aparência. Ao testemunhar a bondade da criatura precisamente enquanto criatura, isto é, ao afirmar que Deus é Deus e, portanto, que o homem é homem e o mundo é mundo, a Bíblia recusa tanto o dualismo maniqueu como toda a forma de panteísmo. Nesta relação transcendental entre Deus e a criatura, está implícito que "dependência radical e realidade autêntica do ente que procede de Deus crescem em igual medida e não em proporção inversa"(18). Se Deus cria a partir do nada, por amor e não por necessidade, então não há rivalidade nem concorrência de interesses entre Deus e a criatura. Pelo contrário, a vontade de Deus é a realização plena e adequada do homem: quanto mais vivo e realizado for o ser humano mais Deus é glorificado.

A fé monoteísta no Deus transcendente e criador dessacralizou a natureza, como bem viu, por exemplo, Max Weber com a sua famosa Entzauberung der Welt (desencantamento do mundo): o Génesis, concretamente, desdivinizou os astros, nomeadamente o sol e a lua, pois já não vê neles deuses, mas simples "luzeiros"(19). Entregando-a à liberdade do homem, a fé bíblica desfatalizou a história. Com igual força o monoteísmo desdivinizou a política e os detentores do poder político. Como seria possível o Êxodo sem a dessacralização do Faraó? O profeta

(17) G. S. Kirk-J. E. Raven, Os filósofos pré-socráticos, Lisboa, 1979, p. 89.

(18) Karl Rahner, Grundkurs des Glaubens. Einführung in den Begriff des Christentums, Friburgo/Br., Basileia, Viena, $1985^{2}$, p. 86.

(19) Gn 1, 14-19. 
Ezequiel adverte o rei de Tiro: "Tu és um homem e não um deus"(20). Jesus deixou aquela palavra decisiva para a secularização da política: "Dai a César o que é de César e a Deus o que é de Deus". Por isso, os judeus e os cristãos opuseram-se frontalmente à divinização dos imperadores romanos, proclamando: "Só Deus é o Senhor"(21).

Enquanto emancipação das realidades terrestres, a secularização é aquele processo mediante o qual vários sectores da sociedade e da cultura - a política, a ciência, a economia, a moral - foram recusando a dependência que no passado tiveram em relação à religião, nomeadamente às instituições e normas religiosas.

Na política, em ordem à sua dessacralização e à consequente separação da Igreja e do Estado, foram decisivas as guerras de religião na Europa. De facto, só mediante essa separação, que significava a neutralidade religiosa do Estado, era possível a garantia da liberdade religiosa de todos os cidadãos sem discriminação. Com a desconfessionalização do Estado e a sua independência face à religião, os cidadãos tornaram-se livres de terem esta ou aquela religião ou nenhuma. No entanto, reflectindo mais profundamente sobre a questão, é necessário afirmar que esta separação não era exigida apenas pela paz social. A própria fé impõe essa separação. De facto, sem ela, espreita constantemente o perigo de idolatria, isto é, de confusão ou até identificação entre Deus e a política. Por outro lado, só homens e mulheres verdadeiramente livres podem dar a sua adesão à fé religiosa e a Deus. Deste modo, como escreveu Edward Schillebeeckx, a Igreja será cada vez mais uma "Igreja de voluntários"(22).

A secularização no sentido da emancipação da razão autónoma e das esferas seculares da vida tem fundamentos bíblicos e pertence à dinâmica adulta do cristianismo, pois é preciso tornar claro que secularização não tem que confundir-se com secularismo, termo criado pela Londoner Secular Society, fundada por G. J. Holyoake em Londres em 1846, cujo programa resumido nesse termo consistia em "interpretar e regular a vida prescindindo tanto de Deus como da religião"(23). A secularização não elimina o Mistério - a finitude não é secularizável -, e o crente maior de idade pressupõe e quer uma razão e um mundo adultos.
(20) $\mathrm{Ez} 28,2$.
(21) Luis González-Carvajal, ob. cit., pp. 30-31.
(22) E. Schillebeeckx, Dios, futuro del hombre, Salamanca, 1971², p. 139.
(23) Luis González-Carvajal, ob. cit., pp. 54-55. 
Se a secularização ou laicidade enquanto separação das Igrejas e do Estado constitui um avanço civilizacional fundamental em ordem à não discriminação dos cidadãos e à salvaguarda da paz, essa separação "não proíbe reconhecer o papel público das religiões e servir-se de diversas formas de colaborações Igrejas-Estado"(24). É significativo que a futura Constituição Europeia, no artigo consagrado ao "estatuto das Igrejas e organizações não confessionais", preveja na alínea 3 "um diálogo aberto, transparente e regular, com estas Igrejas e organizações"(25).

Não foi só a "transcendência religiosa" que perdeu vigor, também a "transcendência política" se desvanece. "Hoje, não é apenas a religião que liga mal os homens, mas a cidadania", nota Dominique Schnapper, que vê no "esgotamento da transcendência colectiva" um desafio maior das sociedades democráticas contemporâneas ${ }^{(26)}$. As sociedades liberais democráticas vêem-se a braços com a dificuldade de fundamentação dos valores, correndo o risco de uma queda no relativismo generalizado. Foi neste contexto que Yves Lambert chamou a atenção para um modelo de "secularização pluralista", isto é, "um modelo no qual a religião não deve exercer domínio sobre a vida social, mas pode desempenhar plenamente o seu papel enquanto recurso espiritual, ético, cultural ou mesmo político num sentido muito amplo, no respeito das autonomias individuais e do pluralismo democrático"(27). As religiões podem dar um

(24) Jean-Paul Willaime, Europe et Religions. Les enjeux du XXI' siècle, Paris, 2004, p. 13.

(25) Jean-Michel Gaillard, "L'Europe sera laïque ou ne sera pas!", L'Histoire, numéro spécial: Dieu et la Politique. Le défi laïque, vol. 289, 2004, p. 102. Após longos debates por causa da inscrição de Deus e da herança cristã na futura Constituição, encontrou-se uma boa solução na seguinte redacção para um dos considerandos do preâmbulo: "Inspirando-se nas heranças culturais, religiosas e humanistas da Europa, cujos valores, sempre presentes no seu património, fixaram na vida da sociedade o papel central da pessoa humana e dos seus direitos invioláveis e inalienáveis, bem como o respeito pelo direito...". Esta redaç̧ão mais abrangente não só tem em conta outras heranças religiosas como, implicitamente, acaba por sublinhar o papel importante do cristianismo para a tomada de consciência da laicidade.

(26) D. Schnapper, La démocratie providentielle. Essai sur l'égalité contemporaine, Paris, 2002, pp. 263-264. Cit. in J.-P. Willaime, ob. cit., p. 11.

(27) Yves Lambert, "Le rôle dévolu à la religion par les Européens", Sociétés contemporaines, vol. 37, 2000, p. 32. 
contributo positivo enquanto "recursos simbólicos", desde que se mostrem capazes de "traduzir a sua própria concepção na linguagem da razão pública" (28). Precisamente face aos enormes desafios éticos com que o nosso tempo se vê confrontado, também Jürgen Habermas manifesta o seu "interesse por uma aproximação respeitosa das tradições religiosas que se distinguem pela capacidade superior que têm de articular a nossa sensibilidade moral", aproximação que ofereceria "o exemplo de uma secularização que salva em vez de aniquilar". Segundo ele, nesta conjuntura, as vozes religiosas têm tanto direito a pronunciar-se como as visões do mundo laicizadas, se pelo menos aceitarem "traduzir a sua mensagem em linguagens públicas e universalmente acessíveis"(29).

Foi Immanuel Kant que preveniu contra a menoridade religiosa culpada enquanto a mais nefasta: "o iluminismo é a saída do homem da sua menoridade de que ele próprio é culpado", e isso "sobretudo nas coisas de religião, porque $[. .$.$] a tutela religiosa, além de ser mais prejudicial,$ é também a mais desonrosa de todas"(30). O nosso tempo é "a idade própria da crítica", e a religião, apesar da sua "santidade" não se lhe pode subtrair, se não quiser expor-se a uma "justa suspeita"(31).

A religião não é o resultado de demonstrações racionais. Isso não significa, porém, que não tenha de apresentar razões e de estar em permanente vigilância para não cair na irracionalidade nem defender doutrinas e atitudes contra a razão. Há de facto aquele dito cínico de Diderot e Voltaire que deve colocá-la em constante sobressalto: temos uma luz - a luz da razão; é fraca, mas é a que temos; vem o teólogo e apaga-a!...

(28) J.-P. Willaime, ob. cit., pp. 13 e 276.

(29) Jürgen Habermas, "Habermas entre démocratie et génétique", propos recueillis par Alexandra Laignel-Lavastine, Le Monde, 20 de Dezembro de 2002, p. VIII. Cit. in J.-P. Willaime, ob. cit., pp. 12-13.

(30) I. Kant, Resposta à pergunta: Que é o Iluminismo?, in idem, A paz perpétua e outros opúsculos, Lisboa, 1988, pp. 11 e 18.

(31) Idem, Kritik der reinen Vernunft I, in idem, Werkausgabe: in 12 Bänden. Band III, Frankfurt/M., 1992 ${ }^{12}$, p. 13 (Prefácio à $1^{\text {a }}$ edição). 
A tentação do fundamentalismo e da guerra religiosa é constante nas religiões, e a explicação parece simples. Há um vínculo extremamente perigoso e até mortal entre religião, poder e, consequentemente, violência. Na religião, o homem procura libertação e salvação. Assim, julgando apoderar-se de Deus infinito e omnipotente, o homem finito e mortal encontraria finalmente a segurança: nada pode abalá-lo, e, por isso, está feliz. Mas, depois, no encontro com outras crenças, outras formas de religião, modos outros de conceber e relacionar-se com o mesmo Deus infinito e omnipotente, é como se as estruturas de segurança desabassem outra vez: como é que Deus pode apresentar-se a outros de modo diferente? As outras religiões surgem, pois, como ameaça radical e, assim, roído pela dúvida na relação com o Infinito, o crente vê-se outra vez mortal, inseguro e infeliz. É intolerável que Deus se revele de muitos modos, quando cada um o considera propriedade exclusiva. Neste domínio, a dúvida é devoradora: o confronto com a alteridade religiosa repõe o medo e a desorientação. A guerra religiosa enquanto tal tem aqui a sua base. Numa primeira leitura, ela justifica-se em nome da verdade. Essa verdade é tanto mais avassaladora quanto é considerada como revelada pelo próprio Deus.

Se há na religião/religiões conceito que não pode subtrair-se à vigilância crítica da razão é o de revelação. Frequentemente o conceito de revelação é este: Deus no seu desígnio oculto e misterioso decidiu manifestar directamente aos profetas e hagiógrafos a sua vontade concretizada num conjunto de verdades sobrenaturais que nada têm a ver com as perguntas e as necessidades humanas mas nas quais é preciso crer por sujeição religiosa. Trata-se de verdades caídas milagrosamente do céu, que, apesar da impossibilidade da mínima verificação, devem ser aceites em bloco, com humildade e sem questionamento.

É claro que, se a revelação não tem ligação intrínseca com as perguntas, aspirações e dinamismos humanos, se tem origem exclusivamente numa autoridade exterior que pode revelar seja o que for e exigir submissão intelectual, não só contradiz a autonomia e dignidade humanas como, com o tempo, será abandonada, por causa da sua total irrelevância. Referindo-se a uma revelação arbitrária, sem articulação intrínseca com a experiência humana, já Kant tinha notado que seria indiferente que as pessoas da Trindade fossem três ou dez: "Que na divindade tenhamos de adorar três ou dez pessoas, tomá-lo-á à letra com igual ligeireza o aprendiz, porque não tem qualquer conceito de um Deus em várias 
pessoas (hipóstases), e, mais ainda, porque desta diferença não pode tirar regras para mudar a sua vida"(32).

Tudo mudará, porém, de perspectiva, se Deus, quando revela, o faz através do psiquismo humano. É sempre Deus que toma a iniciativa, sendo o crente aquele que se dá conta, que descobre o que Deus desde sempre tenta manifestar a todos. Quando se fala em revelação, não se trata de um milagre mediante o qual Deus "ditaria" verdades ocultas e sobre-naturais a certas pessoas, privilegiando umas e discriminando outras. Pelo contrário, "trata-se sempre de uma actividade espiritual humana, às vezes espontânea, por vezes após um largo esforço reflexivo ou à custa de crises tremendas. E é nessa actividade, não num 'ditado' milagroso, que Deus consegue fazer sentir a sua presença e dar-nos a entender a sua salvação"(33). Qual é então - pergunta-se - o lugar e o papel dos profetas, dos hagiógrafos, dos fundadores das religiões? A resposta é: eles são aqueles que com a sua "genialidade" religiosa captam e dão voz ao que Deus desde sempre quer manifestar a todos. Eles descobrem algo, mas esse algo é precisamente o que diz respeito a todos e cada um: só "por isso os outros podem reconhecê-lo e aceitá-lo", apropriando-se. Os crentes não aderem pura e simplesmente porque lhes é dito que se trata da "palavra" de Deus. Se acreditam, "é porque se reconhecem no que ouvem: não o tinham advertido; mas, agora que o ouvem, caem na conta eles mesmos (ou não se reconhecem, e então não fazem caso ou dão uma interpretação diferente do que está a acontecer)"(34). Só podem acreditar com fé pessoal e viva, se eles próprios podem verificar neles, na sua vida, o que lhes é anunciado, portanto, se a palavra reveladora os revela a si mesmos na radicalidade da sua relação consigo, com o mundo, com os outros e com Deus. Vale aqui o princípio: tua res agitur (é de ti que se trata): nesta palavra de revelação, a minha vida, a nossa vida, a história da humanidade e do mundo surgem a uma luz nova, sendo postas a descoberto na sua realidade última e no seu sentido radical e final - vê-se mais e mais radicalmente. Esta é uma concepção de revelação

(32) Idem, Der Streit der Fakultäten, in idem, Werkausgabe. Band XI, Frankfurt/ M., $1991^{9}$, p. 304.

(33) Andrés Torres Queiruga, "Qué significa afirmar que Dios habla? Hacia un concepto actual de Revelación", Sal Terrae, vol. 82/5, 1994, p. 344.

(34) Idem, ob. cit., p. 345. 
enquanto "maiêutica histórica": a revelação bíblica ou de outro livro sagrado é uma "oferta maiêutica": em contacto com ela "ou se reconhece que reflecte a realidade própria mais profunda e então assume-se - livre e criticamente - a sua visão ou não se reconhece e então rejeita-se"(35). A palavra inspirada dos livros sagrados ajuda-nos a "dar à luz o que, desde Deus, somos nós mesmos"(36).

A revelação religiosa nunca é, portanto, directa, pois é sempre experiência com experiências e em experiências. Por outro lado, que a leitura dos livros sagrados nunca pode ser literal mostra-se inclusivamente pelo facto de todos eles estarem eivados de erros científicos e históricos e até de imoralidades. Pense-se, por exemplo, em todos os debates cegos à volta do Génesis e concretamente do mito da criação, quando se não percebeu que se trata de uma mensagem religiosa em linguagem mítica: o doutor Ligtfoot, Vice-Chanceler de Cambridge, pretendeu concluir que a criação do homem teve lugar no dia 23 de Outubro do ano $4004 \mathrm{a}$. C, tendo Bertrand Russell observado acidamente que esse dia foi uma sexta-feira, já que Deus descansou no sábado! Se se tivesse percebido o essencial, nunca teria acontecido o "caso Galileu". Não é preciso ser piedoso para considerar particularmente impiedosa esta impetração bíblica: "Cidade da Babilónia devastadora, feliz de quem te retribuir com o mesmo mal que nos fizeste! Feliz de quem agarrar nas tuas crianças e as esmagar contra as rochas!"(37). Como atribuir a Deus o que não conseguimos pensar de um ser humano bom e decente? Os livros sagrados - a Bỉblia, o Alcorão e todos os outros - não são ditados divinos e precisam, por isso, de uma hermenêutica histórica, não podendo de modo nenhum - exige-o o respeito para com o próprio Deus -, ser engolidos na sua totalidade de modo acrítico.

Historicamente, o conceito de fundamentalismo tem a sua origem numa série de escritos publicados nos Estados Unidos entre 1909 e 1915, intitulados The Fundamentals. The Testimony to the Truth, e a palavra

(35) Idem, "Todavía el Dios de los filósofos?", Selecciones de Teología, vol. 150, 2001, p. 186.

(36) Idem, "La imagen de Dios en la nueva situación cultural", Selecciones de Teologia, vol. 170, 2004, p. 110. No sentido de aprofundar esta penetrante concepção de revelação transcendental e como maiêutica histórica, idem, La Revelación de Dios en la realización del hombre, Madrid, 1987.

(37) Sl 137, 9. 
"fundamentalista" usou-se particularmente para designar Igrejas e denominações protestantes que, por oposição aos teólogos liberais que tinham uma leitura histórica e crítica, defendiam a origem divina literal da Bíblia e consequentemente a sua inerrância absoluta ${ }^{(38)}$. Mas é Albert Schweitzer que tem razão, quando escreveu que o empreendimento da crítica bíblica "representa o mais poderoso que alguma vez a reflexão religiosa ousou e realizou"(39). Sobretudo a partir da crítica de Samuel Reimarus, que mostrou que os Evangelhos e a Bíblia no seu conjunto não podiam continuar a ser tomados à letra, foi tal a crise causada que muitos pensaram que o cristianismo tinha chegado ao fim - muitos seminaristas inclusivamente abandonaram os estudos de Teologia para seguirem outra profissão ${ }^{(40)}$. No século XIX e princípios do século XX, a recusa e o impedimento por parte da Igreja da exegese científica e da hermenêutica histórico-crítica da Bíblia levaram muitos intelectuais, concretamente em França, ao abandono da Igreja e mesmo ao ateísmo ${ }^{(41)}$. Como é sabido, até ao Concílio Vaticano II, os teólogos e os exegetas não tiveram a vida facilitada pelas autoridades eclesiásticas. Para muitos, os problemas continuaram mesmo depois do Concilio.

De modo geral afirma-se que o Islão é incompatível com "axiomas fundamentais do pensamento ocidental, como a democracia e a modernidade", e uma das razões fundamentais estaria precisamente numa leitura literal do Alcorão ${ }^{(42)}$. No entanto, a abertura a uma hermenêutica histórica e crítica do Alcorão, a partir de uma longa tradição no Islão, que faz apelo à ijtihad - um princípio permanente de interpretação -, poderá começar a abrir caminho também no mundo muçulmano, concretamente com "os novos pensadores do Islão". Estes pensadores não hesitam em aplicar este princípio aos textos fundadores - o Alcorão e a Suna -, avançando até às questões teológicas decisivas, que são a revelação e o

(38) Miguel Baptista Pereira, "Modernidade, Fundamentalismo e Pós-Modernidade", Revista Filosófica de Coimbra, vol. I/2, 1992, pp. 224-225.

(39) Albert Schweitzer, Geschichte der Leben-Jesu-Forschung, Tubinga, $1984^{9}$, p. 45.

(40) Idem, ob. cit., p. 67.

(41) Georges Minois, História do Ateísmo. Os descrentes no mundo ocidental das origens aos nossos dias, Lisboa, 2004, pp. 572-603.

(42) Maria do Céu de Pinho Ferreira Pinto, "Infiéis na terra do Islão": os Estados Unidos, o Médio Oriente e o Islão, Lisboa, 2003, p. 39, que dá conta deste debate. 
estatuto do Alcorão enquanto palavra de Deus. Contra a concepção habitual, assente num Alcorão eterno, incriado, preexistente, reconhecem uma revelação progressiva do Alcorão, que continuou durante vinte e três anos após a morte de Maomé, sublinhando, portanto, o seu carácter incarnado, humano e histórico. $\mathrm{O}$ reconhecimento da distância entre o Alcorão e a palavra de Deus, já que esta se dá em linguagem humana, constitui uma verdadeira revolução, como aconteceu com a exegese crítica cristã ${ }^{(43)}$.

A tolerância tal como é hoje entendida resulta de um longo processo ${ }^{(44)}$. Na procura dos caminhos, pegadas e vestígios, que conduziram à tolerância, encontram-se também textos essenciais das três religiões monoteístas - judaísmo, cristianismo e islamismo ${ }^{(45)}$. Assim, por exemplo, no Génesis, narra-se como Deus, depois do dilúvio, estabeleceu uma aliança não só com Noé e os seus filhos, mas com todos os seres vivos ${ }^{(46)}$. No que se refere ao cristianismo, há uma constante: os cristãos devem ser perfeitos como "o Pai celeste", e essa perfeição manifesta-se precisamente no comportamento misericordioso para com todos, incluindo os maus e os inimigos ${ }^{(47)}$; aliás só no fim dos tempos Deus dirá a palavra decisiva sobre o joio e o trigo ${ }^{(48)} ; \mathrm{e}$, face ao anúncio da nova religião que se reclamava de Jesus Cristo, há o conselho do fariseu Gamaliel: "não vos metais com esses homens, deixai-os. Se o seu empreendimento é dos homens, esta obra acabará por si própria; mas, se vem de Deus, não conseguireis

(43) Rachid Benzine, Les nouveaux penseurs de l'islam, Paris, 2004. Ver também Le Nouvel Observateur, Hors-Série: Les nouveaux penseurs de l'islam. Ils dénoncent l'imposture intégriste, ils concilient l'islam et la modernité, $\mathrm{n}^{\circ} 54,2004$.

(44) Não se deve esquecer, por exemplo, que o próprio Locke ainda excluía da tolerância os ateus: "Os que negam a existência de uma divindade não devem de maneira alguma tolerar-se. A palavra, o contrato e o juramento de um ateu não podem constituir algo de estável e de sagrado, pois são os vínculos da sociedade humana, a tal ponto que, suprimida a crença em Deus, tudo se desmorona. Além disso, ninguém pode reivindicar, em nome da religião, o privilégio da tolerância, se elimina radicalmente toda a religião mediante o ateísmo." (John Locke, Carta sobre a tolerância, Lisboa, 2002, p. 118).

(45) Heinrich Schmidinger (Hrsg.), Wege zur Toleranz. Geschichte einer europäischen Idee in Quellen, Darmstadt, 2002.
(46) Gn 9, 1-17.
(47) Lc 6, 27-36.
(48) Mt 13, 24-30. 
destruí-los, sem correrdes o risco de entrardes em guerra contra Deus"(49). Segundo o Alcorão, Alá não exige que os judeus e os cristãos se convertam ao Islão, mas que todos - judeus, cristãos e muçulmanos - sejam fiéis à sua fé: "Não há constrangimento na religião"(50); "Fizemos revelar a Tora. Ela é guia e luz. [...] Fizemos seguir as pegadas dos seus Profetas a Jesus, filho de Maria, confirmando assim a Tora que já tinham. Demos-lhe o Evangelho: nele há guia e luz. [...] A gente do Evangelho julgue segundo o que Deus revelou nele. [...] Se Deus quisesse, ter-vos-ia reunido numa comunidade única, mas dividiu-vos com o fim de vos pôr à prova no que vos deu. Rivalizai nas boas obras! O vosso lugar de reunião, o de todos, está junto de Deus"(51).

Nestes e noutros textos admiráveis, o fundamental é a orientação, pois, mesmo que a sua intenção explícita não tenha sido a tolerância, acabaram por ser, mais tarde, a partir de novas perspectivas, fonte de justificação e legitimação para o pensamento e a acção tolerantes. De qualquer forma, o que impressiona é que ao lado destes textos se encontram muitos outros que foram fonte de intolerância: "a história dos efeitos das Sagradas Escrituras permaneceu ambivalente. Com elas legitimaram-se a tolerância $e$, em termos globais, talvez ainda mais, a intolerância. [...] Prima vista estes textos pouco têm a ver com a tolerância. Mas no decurso da História constituíram os fundamentos religiosos da exigência de liberdade de religião e de consciência e, assim, de tolerância"(52). De facto, foi possível fazer as leituras mais variadas das Escrituras. Lembre-se, neste sentido, o famoso dito de Hegel: a Bíblia é como um nariz de cera, expressão que já vem de Alain de Lille no fim do

(49) Act 5, 38-39.

(50) Surata 2, 256. Segundo este versículo, o Alcorão afirma a liberdade religiosa. Note-se, porém, que as interpretações divergem. A interpretação habitual é restritiva: aplicou-se apenas aos não muçulmanos, pois quem provém de uma família muçulmana "não pode sair do Islão. Segundo a charia, o apóstata, isto é, o que renega a sua religião, é condenado à morte". Mohamed Charfi pensa que diz igualmente respeito aos muçulmanos. De qualquer modo, "a regra da pena de morte para o apóstata desapareceu do direito escrito dos Estados muçulmanos modernos; só subsiste no Irão e nos Estados do Golfo": Mohamed Charfi, "Bourguiba a modernisé la Tunisie en douceur", L'Histoire, cit., p. 86.

(51) Surata 5, 44-50.

(52) H. Schmidinger, ob. cit., p. 23. 
século XII(53). Perante o emaranhado de textos nem sempre em confluência, pois até podem encontrar-se em contradição, impõe-se a tarefa gigantesca da exegese e da hermenêutica. De qualquer modo, se toda a religião tem como ponto de partida esta pergunta essencial: o quê ou quem traz libertação e salvação?, então precisamente a libertação-salvação total é que constitui o fio hermenêutico decisivo para a interpretação correcta dos livros sagrados na sua verdade final. Só a esta luz é que eles são verdadeiros. A sua leitura nunca pode ser fragmentada, já que só no seu todo é que se reclamam da verdade. Em tudo quanto neles se encontra de menos humano ou até de desumano revela-se o que Deus não é. À luz da libertação final, que implica uma antropologia e uma teologia negativas, os livros sagrados são também a história da tomada de consciência por parte dos seres humanos do que Deus não é e do que eles não devem ser para se tornarem verdadeiramente humanos.

A tolerância tem uma dupla vertente: epistemológica - implica uma determinada concepção da verdade, e afectiva - supõe o acolhimento amoroso prático do outro na sua diferença.

Quando a palavra "tolerância" se tinha imposto no século XVIII, logo Mirabeau em 1789 no seu discurso na Assembleia Nacional Francesa, Kant em 1784 no seu escrito Beantwortung der Frage: Was heisst Aufklärung? e Goethe em 1809 nas suas Maximen und Reflexionen, chamaram a atenção para que enquanto mera tolerância no sentido de suportar e aceitar quem pensa de modo diferente sugeriria arrogância e continha até algo de insultuoso. A tolerância tem de significar reconhecimento e promoção da verdade. De facto, ninguém pode pretender ter um saber absoluto ou possuir a verdade toda. Pelo contrário, o saber de cada um e a verdade que deriva desse saber são sempre relativos. Precisamente por isso a coexistência de diferentes concepções e conviç̧ões, em vez de ser uma "falha ou um inconveniente", é sobretudo "uma chance e um desafio" para uma aproximação cada vez maior da verdade "em comum, isto é, em complementaridade recíproca". Já não se trata, pois, de um mero "tolerar" outras convicções, mas de "querê-las" expressamente; passa-se de uma

(53) Textualmente: "A autoridade tem um nariz de cera, podemos inflecti-la em diferentes sentidos" (Auctoritas cereum nasum habet, id est in diversum potest flecti sensum - De fide catholica, I, 30; P- L., 210, 333). Cit. in: Jacques Le Goff, S. Francisco de Assis, Lisboa, 2000, p. 133. 
tolerância "passiva" para uma tolerância "activa", que já se não limita a ser "uma forma de virtude", pois é "uma condição de possibilidade da própria verdade"(54).

Do ponto de vista do diálogo inter-religioso, reconhece-se que todas as religiões, desde que não só não se oponham ao Humanum, mas, pelo contrário, o afirmem e promovam, são reveladas e verdadeiras. Por outro lado, as religiões, que são manifestações e encarnações da relação de Deus com o Homem e do Homem com Deus, são todas relativas, no duplo sentido de relativo: relativas, na medida em que surgem e estão inevitavelmente inseridas num determinado contexto histórico-social, e relativas, no sentido de que estão referidas, isto é, em relação com o Absoluto, mas não são o Absoluto. Assim, se não são o Absoluto, embora referidas a ele, os homens e as mulheres religiosos devem dialogar para melhor se aproximarem desse Mistério divino já presente em cada religião, mas sempre transcendente a cada uma e a todas. Não se trata, portanto, de mera tolerância passiva, que pressupõe ainda uma superioridade de quem tolera o outro considerado inferior. É o próprio Mistério infinito de Deus que exige o diálogo para que os crentes se enriqueçam mutuamente nem sempre a caminho do Mistério que se revela e ao mesmo tempo se oculta, e do qual o ser humano não pode apoderar-se nem dominar. Deste diálogo fazem parte os ateus, pois são eles que permanentemente previnem os crentes contra a idolatria e a desumanidade.

Sobre a ortodoxia tem prevalência a ortopráxis ${ }^{(55)}$, como bem viu Gotthold Ephraim Lessing na sua obra clássica Nathan, o sábio, que apareceu em 1779, sendo pela primeira vez representada em $1783 \mathrm{em}$ Berlim e que é "um dos textos determinantes de toda a história espiritual e cultural que deu origem à ideia europeia de tolerância"(56). O juiz, que não é capaz de decidir sobre qual dos três anéis, símbolos das três religiões monoteístas, é o verdadeiro, diz aos filhos para acabarem com todo o conflito, pois o pai ama os três de igual modo. $O$ decisivo é que mostrem a verdade da fé através das boas obras e do amor ${ }^{(57)}$.

(54) Heinrich Schmidinger, ob. cit., p. 17.

(55) João Maria André, Pensamento e afectividade, Coimbra, 1999, sobretudo pp. 133-136.

(56) Heinrich Schmidinger, ob. cit., p. 283.

(57) G. E. Lessing, Nathan der Weise. Ein dramatisches Gedicht in fünf Aufzügen, Husum/Nordsee, s.d., pp. 64-68. 